\title{
Impact of International Transfer Projects in Developing Vocational Education \& Training in Vietnam
}

\author{
PHUONG Nguyen Thi ${ }^{1 *}$, UTZ Dornberger ${ }^{1}$ \\ ${ }^{1}$ The International SEPT Competence Center, Leipzig University, Germany \\ *Corresponding author: Phuong.nguyen thi@uni-leipzig.de
}

\begin{abstract}
Vietnam has been attracting a lot of foreign investment in different fields as well as exporting numerous goods to the world. Therefore, in order to equip the labor force with good skills to adapt to the international standards, Vietnamese vocational education and training (VET) has been developing the system toward implementing a lot of international transfer projects to transmit technology and knowledge into training and practice.
\end{abstract}

\section{Research purpose:}

As part of the BMBF (Ministry of Education and Research of Germany) funded research project Internationalization of Vocational Education and Training (IntVET,) this research initially study how Vietnamese VET system has been developed based on international transfer projects, then a study on deeply understand the VET system development and business models shall be conducted.

\section{Research motivation:}

Despite the significant amount of researches on technology transfer in VET and international collaborations in higher education sector, little is known about the nature and characteristics or impacts of international transfer projects in developing VET system. Although international transfer projects in VET systems among developed and emerging countries have been fostering popularly, it is a phenomenon that existing research has neglected often.

\section{Research design, approach and method:}

A desk research and semi-structure interviews with six experts who have had experience and knowledge in the field of VET in Vietnam were conducted. The following topics were discussed:

- History of Vietnamese VET system establishment;

- Motivation and progress in implementing of international transfer projects into Vietnamese VET system;

- Viewpoints on the adoption capability or innovation of Vietnamese VET providers toward implementing international transfer projects,

- External factors that drive VET system investing and participating in international transfer projects,

- Major challenges faced by the organization/government in the development of VET.

\section{Main findings:}

There have been many activities and positive effects of implementing international transfer projects toward how Vietnamese VET system developing in order to meet the increasing number of international standards. However, there are still several weaknesses which mainly come from the inconsistency of planning strategies and actions plan in development; social gap, norms and awareness toward VET; unmatched and not-adapted general capacity of Vietnamese VET teachers and learners to requirements set.

\section{Practical/managerial implications:}

The actual results will be a basis for the following individual depth-interview with 20 Vietnamese VET providers toward pilot-based implementation of international transfer projects to study their business models' success factors and innovation. The model then can provide meaningful feedback and data-based recommendations for continuous improvement of the Vietnamese VET system and may enable a broader view of the business models of vocational training providers in an international context to improve the long-term success of internationalization plans in Vietnam.

Keywords: international transfer, internationalization of VET, knowledge transfer, labor force, technology transfer, vocational education and training system. 


\section{INTRODUCTION}

Since the industry revolution has been raising up, human capital has been playing an importance role in sustaining a nation's economic competiveness. Hence, highly skilled workforce is considered as a key nation's resource that can meet requirements of a knowledge-based and innovation-driven economy. These skills somehow can be trained through general education, however, some specific occupational skills are necessarily acquired via vocational education and training (VET). As Hoeckel et al. (2010) pointed out typically VET systems play an important role in supplying these skills. Therefore, VET programs should be designed for learners' knowledge and skills development in order to meet the requirements of industries.

According to previous researches of many authors (e.g. Hilbig, 2017; Hilbig \& Nirenberg, 2019; Ardakani et, 2011) and also mentioned by the National Centre for Vocational Education Research in 2001, the factors influencing demand for VET are globalization, technology development, social needs and values, individual needs and economy issues coupled with regulatory requirements. Here, VET is one of the key components in order to produce qualified workers to contribute to society development and economic growth (Brunello and Paola 2006, King and Palmer 2007, International Labour Office 2010).

The international transfer which include both knowledge transfer and technology transfer is an important topic in international debates related to VET system development (Reddy and Zhao 1990, Allais 2010, King 2014, McGrath 2002). The theoretical basis for transfer in VET (Ramanathan 2011, (Heinzl et al. 2012) as well as the modes of transfer (Khabiri et al. 2012, Fredland 2000) are mostly discussed. International transfer in VET is usually discussed from the perspective of a donor country in order to support a recipient country that is in need of development or reform the VET system. One of the popular examples is the international transfer of Germany's dual training system (Maurer 2019, Li and Pilz 2017). The receiving country perspective is usually related to policy development support (Steiner-Khamsi 2006).

Since early 1990s, many international transfer programs for VET system development have appeared in Vietnam. Therefore, it is now the right time to analyze the impact of these international transfer projects in Vietnam. Hence, this paper is reviewing the development of Vietnamese VET system since its establishment in order to identify the impacts of international transfer projects.

\section{METHODOLOGY}

As part of the BMBF (Ministry of Education and Research of Germany) funded research project Internationalization of Vocational Education and Training (IntVET) this research generated data based on interviews with Vietnamese VET experts. In order to deeply understand the VET system and its development in Vietnam, there was individual depth-interview with six experts who have had experience and knowledge in the field of VET in Vietnam. They are coming from Ministry of Education and Training (MOET), Ministry of Labor - Invalid - Social Affairs (MOLISA), Directorate of Vocational Education and Training (DVET), and some other organizations which used to play important parts of moderating, supporting collaborative activities and/or participating in connecting international transfer projects to VET providers in Vietnam such as Deutsche Gesellschaft für Internationale Zusammenarbeit $\mathrm{GmbH}$ (GIZ), Vietnam-Japan Cooperation Center, Ho Chi Minh City University of Technology and Education (HCMCUTE), and Friedrich Naumann Foundations (FNF) (see table 1).

Table 1: List of experts

\begin{tabular}{|c|c|c|c|}
\hline Experts & Position & $\begin{array}{c}\text { Years of } \\
\text { experience }\end{array}$ & Title \\
\hline MOET & $\begin{array}{c}\text { Senior } \\
\text { Advisor }\end{array}$ & 42 & Professor \\
\hline DVET & $\begin{array}{c}\text { Senior } \\
\text { Advisor }\end{array}$ & 41 & Ph.D. \\
\hline FNF & $\begin{array}{c}\text { Sr. Project } \\
\text { Officer }\end{array}$ & 20 & Master \\
\hline VJCC & $\begin{array}{c}\text { Vice Rector } \\
\text { Vice Rector }\end{array}$ & 30 & Ph.D. \\
\hline HCMC & $\begin{array}{c}\text { Senior } \\
\text { UTE }\end{array}$ & 40 & Mh.D. \\
\hline
\end{tabular}

(Source: Author, 2021)

As a two-way method of collecting data, semi-structured interview can get the full spectrum of participants' observation and obtain an in-depth understanding of the research subject.

In detail, the following topics were discussed:

- History of Vietnamese VET system establishment;

- Motivation and progress in implementing of international transfer projects into Vietnamese VET system;

- Viewpoints on the capability of adoption or innovation of Vietnamese VET providers toward implementing international transfer projects;

- External factors that drive VET system investing and participating in international transfer projects;

- Major challenges faced by the organization/government in the development of VET. 
Each interview lasted around one hour and the interviews were tape recorded and fully transcribed for answering these questions.

\section{RESULTS AND DISCUSSION}

VET in Vietnam has a long story of development which is associated with the emergence and existence of wet rice civilization and traditional craft villages. The Viet ancient passed the craft profession to many generations to produce and maintain life. Those were forms of vocational transmission in imitation of prehistoric nature to conscious imitation alongside groups and associations. Since the $11^{\text {th }}$ century coming to the Feudal time which VET was affected a lot from Chinese under thousand years of domination with strong influence of Confucian. International transfer could be seen in this period in form of introduction of Chinese education, Confucian education and still last until today with the methodology of teacher-centre and rote learning with the highest respect for teachers and lack of encouragement for students to ask questions (Dang 2009; Ho and Reich 2014; Ngo 2011; T. T. H. Nguyen 2012; Welch 2010).

VET system began to take shape gradually since end of the $19^{\text {th }}$ century with formal training organizations such as Hue School of Practical Technology (1889), Saigon School of Practical Technology (1898), Hanoi School of Practical Technology (1898), and Hai Phong Practical Technology School (1913). At the beginning of the $20^{\text {th }}$ century, more VET institutions were established as vocational training classes at factories and vocational school. At this time, the number of students was very small and just enough to provide the necessary workforce for light industry, consuming industry and natural resource extraction industry in order to bring profit to the French colonialists. At this time the VET system had experienced some international knowledge and technology transfer from France via basic training and on-job-training since French companies built a number of industrial bases in the mining, mechanics, service industry and processing industry which developed in four main areas: mining, production of construction materials, transportation engineering, and the processing industries. A modern science-oriented education including general education with foundation knowledge (i.e. physics, chemistry, language) was introduced to Vietnamese (Ho and Reich 2014; Vo 2012), is still now applied in current Vietnamese tertiary education where is still some similarities to French education system including its central management $(\mathrm{H}$. P. Tran 1998).

From 1954 to 1975 , the country was temporarily divided into two regions. In the North, vocational training had grown rapidly with effectively support from socialist allied countries. The transfer activities dealt with importing technology and competencies to restore and build the base of Vietnam emerging's industry sector focusing on textile and garment, machinery engineering, state-owned farms, transportation and construction, education and health, etc. Due to the requirement of developing human resources for developing the North and liberating the South, the government established the General Department of Training Technical Workers under the Ministry of Labor. This is a historical milestone marking the strong development of Vietnamese VET system. Then, there was a dramatically change after the independence. International cooperation in Vietnamese VET expanded to participate in and host conference of the leaders of VET institutions in those socialist countries, to send about 80,000 young people and workers to vocational training courses in former Soviet Union, German Democratic Republic (former), Czechoslovakia (former), China, Korea, Hungary, Romania, Brazil, Poland and Bulgaria. Coming back from the training abroad, they had made important contributions to the country. There was influence of the socialism (another term was Soviet) education to VET during this time in general education (Math, Advanced Math 1 and 2), political education (Leninism or Marxism philosophy), and the emphasis of theory-based classes over workshop and working experience (Mac et al. 2012; Ho and Reich, 2014; Phan, 2015). During this time, VET was also got a little influence from the USA under American empire. Starting in 1971, the government opened a number of community universities (following the US community college model) such as Tien Giang Community College (focuses on agriculture) in My Tho; Duyen Hai (focuses on fisheries) in Nha Trang; Quang Da in Da Nang (1974); and Long Ho (sunfinished still 1975) in Vinh Long; the Regina Pacis University, founded by Catholicism, exclusively for females (1973).

Since the Renovation 1986, Vietnam has changed once again dramatically, especially in VET system. The number of VET schools were reduced from 279 in 1987 to 129 in 1998 due to the low demand for state-owned enterprises. Therefore, when the country got opened for foreign investment, VET institutions were unable to respond to the demand for highly skilled workers. There was once again the need of VET system development, to foster the economy and social development of the country.

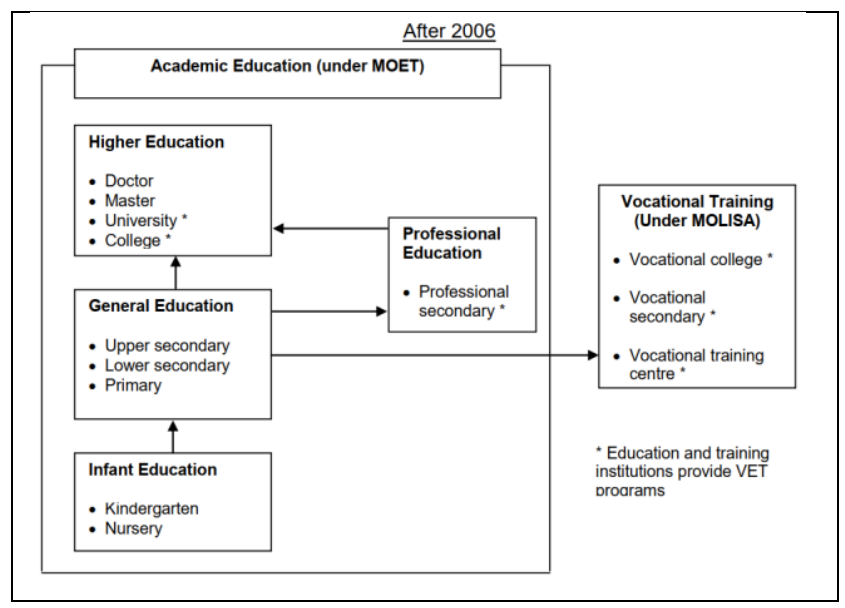




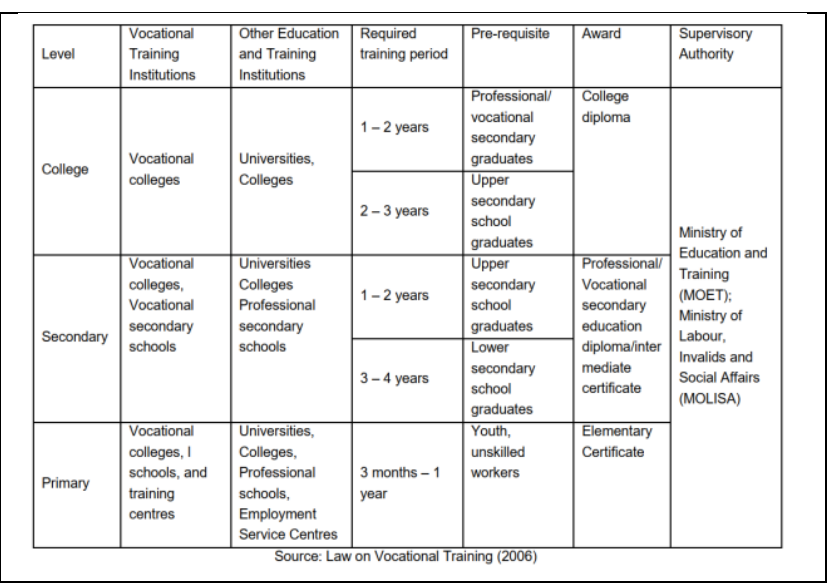

Fig. 1: VET system and qualifications in Vietnam

(Source: Law on Vocational Training, 2006)

The General Department Vocational Training (GDVT), later on shifted into Ministry of Labour, Invalids and Social Affairs (MOLISA) started revising the 2006 Law of Vocational Training and introduced the new vocational training strategy 2011-2020 with the desire of meeting the labor market demands both in quantity, quality and vocational system structure. Enforcement of this law has strengthened VET in Vietnam, however, the existing system is still complex and there is unclear demarcation of responsibility and accountability in VET between MOET which retains some policy functions, MOLISA, and other supervisory ministries. Since then, Vietnamese VET system has changed frequently and has had several supervisory ministries, making it difficult to get reliable and comprehensive statistics from time to time. Until 2018, with a network of 1,979 VET institutions, including 395 colleges, 545 intermediate schools, and 1,039 vocational education centers, the quality and quantity of VET graduates have contributed to the economics a lot. In addition, the Law on VET defines the objective of international cooperation in VET as "improve the quality of VET in the direction of modernity, approaching the advanced vocational education in the region and in the world". It opened gate for welcoming more international collaboration in form of joint training; establishment of representative offices of foreign VET institutions in Vietnam; cooperating in scientific research, transferring technology and organizing scientific conferences and seminars; fostering and exchanging teachers, management staffs and students; exchanging information for training activities; providing training programs; exchanging publications, documents and training results; participating in regional and international educational organizations and professional associations; opening representative office of Vietnamese VET institutions abroad. This is a positive point that Vietnam is becoming one of the potential partners and attractive market for educational cooperation.

The push for the development of the VET system came mainly from the rapid growth for foreign direct investment (FDI) in the country. Ranked the $14^{\text {th }}$ in the world (2020) for its population of more than 96.2 million and belonging to group of countries with the highest economic growth rates in the world over the past two decades together with its competitive costs and low wages, Vietnam has become one of worldwide hotspots in FDI (VCCI, 2019).

According to Industrial Location Theory (Grabow, 1995), one of the hard location factors is labor market. It is not only about having enough employees but also the qualifications of these employees plays an important role. Consequently, the Vietnamese government recognized the essential of FDI in VET since early by issuing a Draft Decree on Cooperation and Investment in Education and Training Involving Foreign Partners. This Decree encourages collaboration and investment in all types and relevant activities in a wide range fields of education and training covering industries and services such as IT \& telecommunications, mechanics, food technologies, electronics and electronic commerce, natural sciences, engineering, health, environment, agriculture, tourism, business management, finance \& accounting, international laws and foreign languages, etc. Furthermore, under the AANZFTA, Vietnam has made several commitments that allow $100 \%$ foreign-invested VET entities. Since the late 1990s, which particularly support of the Asian Development Bank (ADB), Germany, Korea and Japan, there have been various multilateral and bilateral donor projects providing technical and financial assistance to Vietnamese VET system.

The Vietnamese government has embarked on modernization and industrialization reform programs to enhance its standing in ASEAN and enhance Vietnam's competitiveness in the process of international economic integration. These initiatives aim to develop a more qualified workforce by facilitating the expansion and diversification of educational training programs. A major contribution to this approach has not only been the international adoption but also the adaptation of international VET programs and reforms (Reich and Ho 2017).

These are the motivation for Vietnamese VET providers to implement international transfer projects. Under MOLISA management, a project named Vocational and Technical Education was launched from 1998 to 2008. It received supporting from ADB as well as France, Japan and Nordic countries to establish 15 VET schools, to develop standardized skills for 48 occupations, to apply accreditation with national testing and certification, and to pilot labor force information systems. In addition, to develop labor market information centers with MOLISA and provincial authorities, to strengthen the quality of VET teachers, and to develop national still standards in one industry sector, in partnership with MOLISA, the International Labor Organization was implementing the Labor Market Project which launched since 2008 in two years with US\$18.3 million funded by European Union. Several activities toward assisting with curricula reform, improving teaching and learning materials and 
in-service teacher training have been advised in a project of German Technical Cooperation (GTZ) on Promotion of Technical and Vocational Education and Training (2006 to 2010) on labor market oriented skills training for sectors with potential growth and employment. Besides, there have been many international transfer projects in VET coming from Korea, Japan and Australia, Canada and many others' International Cooperation Agencies.

There have been many ambitious plans by the Vietnamese Government to address VET needs as well as to double rural incomes by 2020 , such as:

In 2009, the project "Renewal and Development of Vocational Training System by 2020" together with the allocation of $\$ 1.4$ billion to train 1 million worker in rural to increase the rate of skilled workers to $50 \%$ by 2020 were launched announced by GoV.

An investment of US\$2.29 billion provided via the State budget and ODA was used for the project aiming to foster the establishment of VET institutions and training 40,000 vocational trainers.

One of the advantages for Vietnamese VET is that the country is stable in terms of politics and socio-economic development. The socio-economic development strategy for the period 2011-2020 set the requirements of restructuring economic and innovating the growth model together with strategy and master plan on human resource development. These advantages are the basic premise to carry out fundamental and comprehensive renovation of Vietnamese education and strengthen international cooperation in education. Faced with the new requirements of industrialization and modernization of the country and international integration, Resolution No. 29/NQ-TW dated November 4, 2013 of the 8th Plenum of the 11th Central Committee and the Resolution of the National Congress of Deputies, the 12th National Party Meeting of the Party had determined that one of the key tasks in the next 5 years was to fundamentally and comprehensively renovate education and training, and improve the quality of human resources to meet the requirements of the labor market, which associated with the needs of socio-economic development and progress of science and technology. On the other hand, Vietnam's signing and accession to the new generation of bilateral and multilateral free trade agreements (FTAs) has posed many challenges for the country in transforming the economic and structuring labor forces. Vietnam is actively and proactively integrating into the international community. Up to now, there are 13 FTAs which have come into effect, many new ones have been signed or are being negotiated. This is a big advantage for international transfer projects and collaboration in VET.

Last but not least, as trend and strategy, on May, $23^{\text {rd }}$ 2014 the Decision No 761/QD-TTg was issued on approving the project to develop 45 public high-quality VET institutions until 2020 (Project 761). These institutions have been selected to prioritize concentrated and synchronous investment according to the criteria of high-quality VET schools, capable of training a number of occupations recognized by advanced countries in the ASEAN region or internationally. According to the expert from DVET sharing piece of MOLISA report, in the period 2014-2019, these high-quality VET institutions have achieved some outstanding results:

- The quality and effectiveness of vocational training have changed positively with over $75 \%$ of fresh graduates who could find jobs or self-employment immediately.

- The number of enrollment increases every year. Comparing to 2015, the number of enrollment in 2017 nearly doubled, and from 2018, the scale increased from $10 \%$ to $15 \%$ on average.

- 251 occupations in 49 key industries have been centrally invested in order that 154 occupations from 27 industries have reached international level and 60 occupations in 18 industries are at the ASEAN regional level, and 37 occupations in 28 industries are at the national standards.

- These VET instructions have received and transferred 34 key international occupations in which 12 from Australia, 22 from Germany. These pilot courses are at scale for 2000 students. Graduates will be awarded Australian or German diploma.

- 682 teachers of these VET institutions are synchronously trained at home country and abroad. These VET institutions have been also assessed by international partners to meet standards to organize training.

- Schools management meet domestic quality accreditation standards. Among those are 21 schools which operating British quality management process, 8 pilot schools for international accreditation having basically achieved the standards as assessed by British and German experts.

- 3 VET colleges piloting renovation in operational autonomy mechanism according to Resolution No. 77/NQ-CP, dated October, $24^{\text {th }}$ 2014 of the Government reached outstanding achievements in term of enrollment results, training quality and development of teaching staff and facilities.

- Many large corporations and enterprises have paid attention and directly participated in VET such as Vingroup, Sungroup, FPT, Samsung, Thaco, etc. Cooperation between VET schools and industry has been strengthened in the direction of increasing training at enterprises, training on orders of recruitment, technology 
transfer. Therefore, most of high-quality training programs have ratio of over $30 \%$ time practicing at enterprises and over $50 \%$ time of practicing per whole program.

Although since the early stage of establishment, there has been international cooperation in Vietnamese VET and international cooperation including international transfer projects has taken place in a variety of forms and methods with many efforts, the positive impacts and development can be seen only in some VET institutions. For the vast and major VET institutions along the country, international cooperation in the field of VET is still situational, with no clear strategic direction wisely. Effective cooperation programs and projects have not been as expected, agreed by most of the experts during interviews. These weaknesses can be seen as below:

The Law on VET took effect from July, $1^{\text {st }}$ 2015 but it still lacks many standards, norms and regulations. The norms related to international transfer projects with its standards were not yet available, so the process of piloting and implementing new issues was slow. Decision No. 761/QD-TTg on high-quality VET schools did not specify a number of contents related to the association with enterprises in training, practice time ratio, internship at enterprise, lack of evaluation on success measurements such as the percentage of students graduating from each program and level as well as the evaluation on skills comparing with each occupational skills standards, lack of evaluation on entrance for foreign languages and computer skills; it also lacks of evaluation on the application of digitalization in management, methodology toward Industrial Revolution 4.0. especially, the ability on communicating in foreign languages and different cultures among Vietnamese VET teachers, managers, students and international experts have led to difficulty in understanding each other and progress. During implementing international transfer projects such as the Project 761, there was lack of initial agreement and consistency in the list of key occupations in which some were considered not close to reality and future requirements. The network of vocational training institutions fluctuated due to the implementation of restructuring policies in the spirit of Resolution No. 19-NQ/TW of the 6th Plenum of the 12th Central Committee on continuing to renovate the organization and management system. This is when schools being invested into high-quality schools merge with training institutions with weak training capacity, it will lead to shared resources and not enough to meet the original target requirements. Schools invested to provide high-quality vocational training have a mission to lead, spread and influence the whole system while the system needs to focus on developing the number and scale of training. This becomes a big challenge in the context and conditions of Vietnam. Another major concern was that the complicated from the board management of different ministries and function has led to conflict and slow reaction of VET providers.

- The gap between the rich and the poor among the population groups and the uneven development between localities continue to be the cause of the lack of equality in education access opportunities and the gap in education quality among learners and regions. This is a difficulty for international cooperation in VET.

- There is still prevention from subsidized thinking, cognitive inertia, and bureaucratic behavior in dealing with vocational education of many levels and sectors, teachers and vocational education administrators, who cannot keep up with the rapid development of socio-economic, science and technology; the sickness of achievements, vanity, and pursuit of qualifications among cadres and people is slow to be overcome. This is a difficulty of developing VET and limits to international cooperation.

- The gap of development in socio-economic, science and technology, education and training between Vietnam and advanced countries in the region and the world tends to increase. Facing a dynamic and rapidly changing labor market in the process of economic development and international integration, still many VET institutions have not changed to keep up with the requirements. The strategic objective of vocational training in the period 2011-2015 is to train about 9.6 million new skilled workers, but the implementation result was only 9.1 million people, of which enrollment at vocational intermediate level and vocational college is only $53 \%$ plan; annual enrollment of intermediate professional level was reduced by $15 \%$ /year. The structure of vocational education enrollment was still inadequate, mainly at the elementary level and under 3 months (accounting for 88\%), the intermediate level and college level only accounted for about $12 \%$.

- The imbalance in the structure of training professions between regions, has been slowly overcome and not met the human resource needs of the society. Vocational education enrollment is difficult, especially in heavy and hazardous occupations and professions. Implementation of high-quality vocational training (Project 761 of key vocational development, high-quality vocational schools and piloting international and regional vocational training under the transfer program 
from abroad) is still slow.

- The network of vocational education institutions is still inadequate, not properly distributed among regions, not planned for each industry, profession and level of training. The construction and development of a contingent of teachers and vocational education administrators has not been given due attention. The number of teachers and administrators is both redundant and insufficient. The structure of vocational training for VET teachers is not reasonable, some occupations do not have basic trained teachers, vocational skills are limited, and the percentage of integrated teachers is still low compared to the requirements of the training program. Foreign languages and computer skills of VET teachers are still weak, limiting their ability to update new technologies, to apply informatics and modern pedagogical methods. The ability of VET teachers to develop programs, compile curricula, and vocational training materials is still limited. In international cooperation in the field of VET, although having access to new knowledge, new technologies, modern vocational training models, expanding experience exchange, having opportunities to approach and attract external resources for the development of VET; the general capacity of Vietnamese VET teachers has not met and promptly adapted to the requirements set.

- Facilities and equipment of many VET institutions have not met the requirements. Vocational training programs and textbooks still have many formal contents, which have not been regularly updated and supplemented to suit the requirements of the labor market. The training quality and effectiveness of many vocational education institutions are still low, not organically linked to the human resource needs of each branch and each locality; the relationship between vocational education institutions and enterprises is still loose; students and graduates are still weak in foreign languages and soft skills. National vocational skills standards are slow to be promulgated; quality does not meet the requirements of enterprises and the labor market.

- The number of VET institutes in enterprises is still small and unable to meet the demand for skilled labor of the enterprises themselves. The relationship between VET institutions and enterprises is still weak (both in terms of responsibilities and interests), in fact, schools still mainly train according to their "supply" capacity and not really provide training according to " demand" of the business. Many schools only train the basic knowledge and skills that they have, but not towards the knowledge and skills that the market really needs.

The cause of industrialization and modernization of the country and international integration requires high-quality human resources, while the national resources and the ability to invest in education of the State and the majority of families are still inadequate and limited. The quality of human resources is still low, posing heavy tasks and great challenges to the development of education and training. The ongoing strong integration process also poses challenges for VET institutions. Experts have pointed out that in order to survive and develop, VET institutions need to constantly change to improve their competitiveness to attract students and international investors in human resource training cooperation. Along with the strong development of Industry 4.0, recruitment needs will change. This is the challenge of VET institutions, who want to be able to be autonomous and stand firmly in the context of fierce competition, must develop in the direction of expanding cooperation with other countries having good training programs in the region and the world.

\section{CONCLUSION}

Vietnam has been engaged in international transfer since early and get along with its VET development so that the need of labor market demand can be satisfied due to world revolution of industrialization and internationalization. International transfer projects happened in VET help the VET system develop in a better way with impacts clearly seen in terms of providing and improving more qualified curriculums, quality of trainers and teaching methods, building and enriching key resources for VET providers and satisfying the need of industry via stronger relationship among government, VET providers and enterprises.

In general, VET development with its international transfer projects plays an important role in supplying human resources for growth, increasing labor productivity, and helping Vietnam escape the "middle income trap". In the last three years, vocational training has undergone many successful innovations. Enrollment results are twice times higher than the previous period. Most VET schools, especially in key economic regions and urban areas, have escaped the difficult situation of enrollment to begin restructuring, improving training quality and increasing their scales. Last but not least, international transfer projects in VET have been giving impacts for the Vietnamese government toward renewing the legal framework and supporting policies of the government to renovate and integrate into the world in training, improving the quality of vocational teachers and raising awareness of parents and students about vocational training pathways and job opportunities. 
Our study also shows that to deal with existing weaknesses in order to implement international transfer projects better in VET, it is recommended that:

- There should be more strategies and policies from VET providers to attract more talents who have knowledge and experiences internationally and to develop in the direction of expanding cooperation with other countries having good training programs in the region and the world.

- Teaching Vietnamese language to overseas Vietnamese and foreigners in Vietnam and attracting overseas Vietnamese to participate in domestic teaching in VET;

- Implementing autonomous mechanism is a breakthrough step which can help VET providers since it is seen as the key to the innovation of vocational education, helping to address current as well as future problems in the system of vocational education.

- There should be more activities in researching and applying standards of countries in the region and the world to develop training standards, facilities' standards, standards of teachers, lecturers, quality management standards; in developing national and international vocational skills standards which are recognized by countries in the region and worldwide; in conducting skills assessment and vocational skills recognition between Vietnam and other countries in the ASEAN region.

- It is necessary for reviewing the network of Vietnamese VET institutions, including those in the planning for high-quality schools and schools reaching regional and international levels. It is also a must to review and re-evaluate the integration progress of 45 VET institutions that have been oriented to focus on investing in high-quality schools and schools planned for key occupations at ASEAN and international levels; and to review of planned ASEAN and international occupations in intermediate schools and colleges with training criteria and standards approaching the level of advanced countries in the region and the world.

- Continue to receive transferring of recognized 72 sets of international-level programs from abroad, which are accredited by the transferring country or by a reputable international education and training organization, which is accredited and recognized to be of international quality; organize pilot training at college level for 32 key international occupations; develop 25 sets of specialized English programs for occupational groups at national, ASEAN and international levels; develop software to simulate the practice of a number of curricula for key occupations at the national level;
- $\quad$ Provide training and fostering teachers towards international standards; the teachers and administrators of the international transfer programs must meet the teacher standards of the transferring countries and be recognized by the transferring countries; Organize the transfer of teacher training programs on international pedagogical skills and professional skills of 45 high-quality schools; provide training and fostering managers to approach international standards, towards professional managers.

\section{ACKNOWLEDGMENTS}

The work is financed by the Ministry of Education and Research of Germany. I gratefully acknowledge the contribution of the experts who sharing their points of view as well as the valuable information in field of VET and its related connection. Last but not least, I am so thankful for the support by my colleagues in the IntVET project team in Leipzig University.

\section{REFERENCES}

[1] K. Hoeckel, S. Field, T. Justesen, M. Kim. 2010. Learning for Jobs. Learning for Jobs.

[2] Hilbig, Romy, and Natalie Nirenberg. 2019. "Becoming International - The Business Model Innovation Process of VET Providers Presented at EURAM 2019 - Exploring the Future of Management ,.” In , 0-40.

[3] Abdelkafi, N., Hilbig, R. and Laudien, S.M. 2018. "Business Models of Entrepreneurial Universities in the Area of Vocational Education - an Exploratory Analysis."

[4] Abdelkafi, N., Hilbig, R. 2014. "Business Models of International Operating German Educational Services - The Power of the Franchising Model."

[5] Abdelkafi, Nizar, Sergiy Makhotin, and Thorsten Posselt. 2013. "Business Model Innovations for Electric Mobility-What Can Be Learned from Existing Business Model Patterns?" International Journal of Innovation Management 17 (1).

[6] Brennan, Louis, Kasra Ferdows, Janet Godsell, Ruggero Golini, Richard Keegan, Steffen Kinkel, Jagjit Singh Srai, and Margaret Taylor. 2015. "Manufacturing in the World: Where Next?" International Journal of Operations and Production Management 35 (9): 1253-74.

[7] Fredland, Richard A. 2000. "Technology Transfer to the Public Sector in Developing States: Three Phases." Journal of Technology Transfer, no. 25: 
$265-75$.

[8] Heinzl, Joachim, Ah-Lian Kor, Graham Orange, and Hans Rüdiger Kaufmann. 2012. "Technology Transfer Model for Austrian Higher Education Institutions." Journal of Technology Transfer 38 (5): 607-40.

[9] Khabiri, Navid, Sadegh Rast, and Aslan Amat Senin. 2012. "Identifying Main Influential Elements in Technology Transfer Process: A Conceptual Model." Procedia - Social and Behavioral Sciences 40 (January): 417-23.

[10] King, Kenneth, and Robert Palmer. 2007. "Technical and Vocational Skills Development." World Development, no. October: 1-32.

[11] Lund, Henrik Brynthe, and Asbjørn Karlsen. 2020. "The Importance of Vocational Education Institutions in Manufacturing Regions: Adding Content to a Broad Definition of Regional Innovation Systems." Industry and Innovation 27 (6): 660-79.

[12] Maurer, Markus. 2019. "The Challenges in Policy Transfer in Vocational Skills Development - An Introduction. Gut Zum Druck Ready to Print Bon à Tirer," Peter Lang AG, Bern.

[13] Ramanathan, K. 2011. "An Overview of Technology Transfer and Technology Transfer Models." http://www.apctt.org/.

[14] Reddy, N. Mohan, and Liming Zhao. 1990. "International Technology Transfer: A Review." Research Policy 19 (4): 285-307.

[15] Reich, Ann, and Tien Thi Hanh Ho. 2017. "Adapting International Influences and Retaining 'Vietnamese Character' in Vet in Vietnam." Technical and Vocational Education and Training 25: 135-47. https://doi.org/10.1007/978-3-319-47859-3_8.

[16] Steiner-Khamsi, Gita. 2006. "The Economics of

[28 Policy Borrowing and Lending: A Study of Late

Adopters." Oxford Review of Education 32 (5): 665-78.

[17] Kohlhammer, 1995. Weiche Standortfaktoren / von Busso Grabow; Dietrich Henckel; Beate Hollbach-Grömig unter Mitarb. von Nizan Rauch .. . - Stuttgart :- 407 S.; graph. Darst.; 22 $\mathrm{cm}$. - (Schriften des Deutschen Instituts für Urbanistik ; 89). - ISBN 3170137344, 9783170137349

[18] M.W. Johnson, "Seizing the White Space: Business Model Innovation for Growth and Renewal" (Boston, Massachusetts: Harvard Business Press, 2010);
[19] Dodgson, M. (2015). The Oxford handbook of innovation management (1. publ. in paperback.). Oxford: Oxford University Press.

[20] http://www.hanoimoi.com.vn/tin-tuc/Xa-hoi/8888 76/dao-tao-nghe-chuyen-huong-canh-tranh-bang-h op-tac-quoc-te

[21] https://nivet.org.vn/nghien-cuu-khoa-hoc/hoat-don g-khoa-hoc/item/1033-boi-canh-nang-cao-chat-luo ng-hop-tac-quoc-te-trong-giao-duc-nghe-nghiep

[22] https://seafit.org.vn/hop-tac-quoc-te-trong-giao-du c-nghe-nghiep-va-nhung-van-de-dat-ra-doi-voi-vie t-nam/

[23] https://internationaleducation.gov.au/International-ne twork/vietnam/publications/Documents/VET\%20Bac kground $\% 20-\% 20$ for $\% 20$ AEI\%20website.pdf

[24] Vo, T. X. (2012). Lịch sủ giáo duc đào tạo nghề Việt Nam [History of Vietnamese vocational education]. HoChiMinh City: HoChiMinh National University.

[25] Tran, H. P. (1998). Vietnamese higher education at the intersection of French and Soviet influences. Ph.D thesis, State University of New York.

[26] Mac, V. T., Pham, X. T., Nguyen, Q. V., Nguyen, T. H. N., Mai, P. B., Dang, T. H., Nguyen, T. M. N, Phung, L. K, Ha, D.N, Nguyen, T. L. H, Le, A. T, \& Nguyen, B. D. (2012). Báo cáo dạy nghề Việt Nam 2011 [Report on vocational training in Vietnam 2011]. Hanoi: Vien Nghien cuu Khoa hoc Day nghe - Research Institute for Vocational Training Sciences.

[27] Ho, T. H. T., \& Reich, A. (2014). Historical influences on vocational education and training in Vietnam. Retrieved from VOCED http://avetra.org.au/wp-content/uploads/2014/05/ Abstract-13.pdf 